\title{
Farm Ponds as Wildlife Habitat in the Driftless Area Ecoregion
}

In the Driftless Area Ecoregion of southeastern

Minnesota, western Wisconsin, and northeastern Iowa, natural wetlands are scarce. Constructed agricultural ponds represent important alternative breeding habitats for amphibians and other wildlife. This region contains thousands of farm ponds constructed with financial assistance from the U.S. Department of Agriculture and the respective states. The purpose of these farm ponds is to prevent soil erosion and create wildlife habitat, yet little information was available to determine if such ponds benefit wildlife.

During spring and summer of 2001 and 2002, the Upper Midwest Environmental Sciences Center (UMESC) initiated a study to identify the species of amphibians and other wildlife that inhabit both natural and artificially constructed farm ponds in southeastern Minnesota. We also studied the relation between the diversity, reproductive success, and rates of deformities among amphibians and the management practices used by farmers near these ponds.

We collected data from 40 randomly selected ponds, 10 ponds in each of four surrounding landuse classes: row-crop agriculture, grazed grassland, ungrazed grassland, and natural wetlands. We identified 10 species of amphibians inhabiting the ponds, as well as numerous birds and mammals.

Amphibians inhabited all the types of farm ponds we studied, and few were deformed. We observed many of the same species in both constructed farm ponds and natural wetlands; in fact, some species were more common in constructed ponds. However, some species (the spring peeper and gray treefrog) had low reproductive success in grazed ponds compared to the other pond types. We attribute the poor performance of grazed ponds to livestock disturbance (wading and defecating), which degrades water quality and prevents the establishment of vegetation. Ponds used to provide water for livestock had elevated concentrations of nitrogen and higher turbidity. Overall, we observed that amphibian reproductive success was greatest in ponds with sparse vegetation, low concentrations of nitrogen, and no fish.

We identified 10 species of amphibians living and reproducing in the ponds, including the tiger salamander (Ambystoma tigrinum), American toad (Bufo americanus), gray treefrog (Hyla versicolor), western chorus frog (Pseudacris triseriata), spring peeper (Pseudacris crucifer), green frog (Rana clamitans), wood frog (Rana sylvatica), northern leopard frog (Rana pipiens), pickerel frog (Rana palustris), and the blue-spotted salamander (Ambystoma laterale). The blue-spotted salamander was a new record for Houston County, Minnesota. Amphibian species richness among the pond types was similar and deformity rates were low ( $<5 \%$ deformed individuals) at all ponds. The parasite Ribeiroia (linked to amphibian malformations elsewhere) was identified at 3 of 16 ponds examined for parasites in 2000 and 6 of 13 ponds

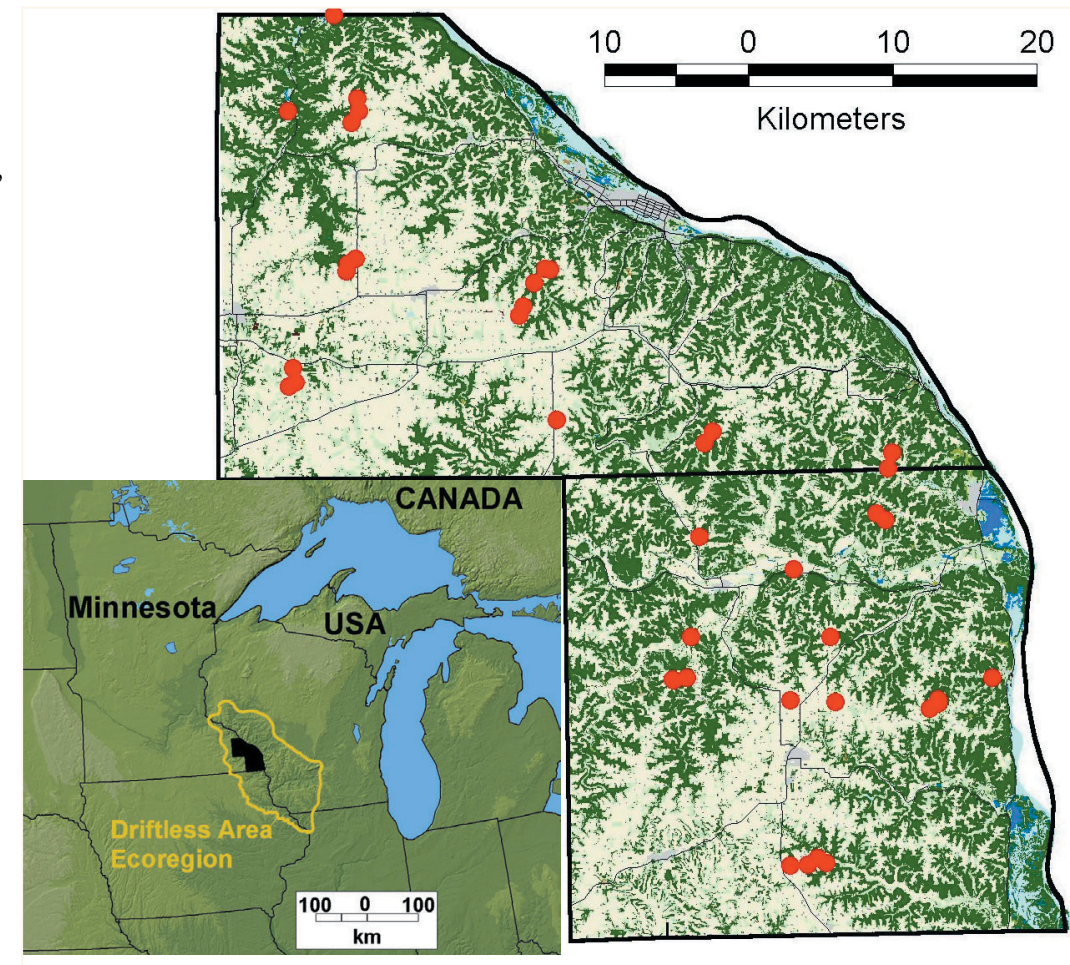

Farm pond study sites in southeastern Minnesota, Houston and Winona counties. 


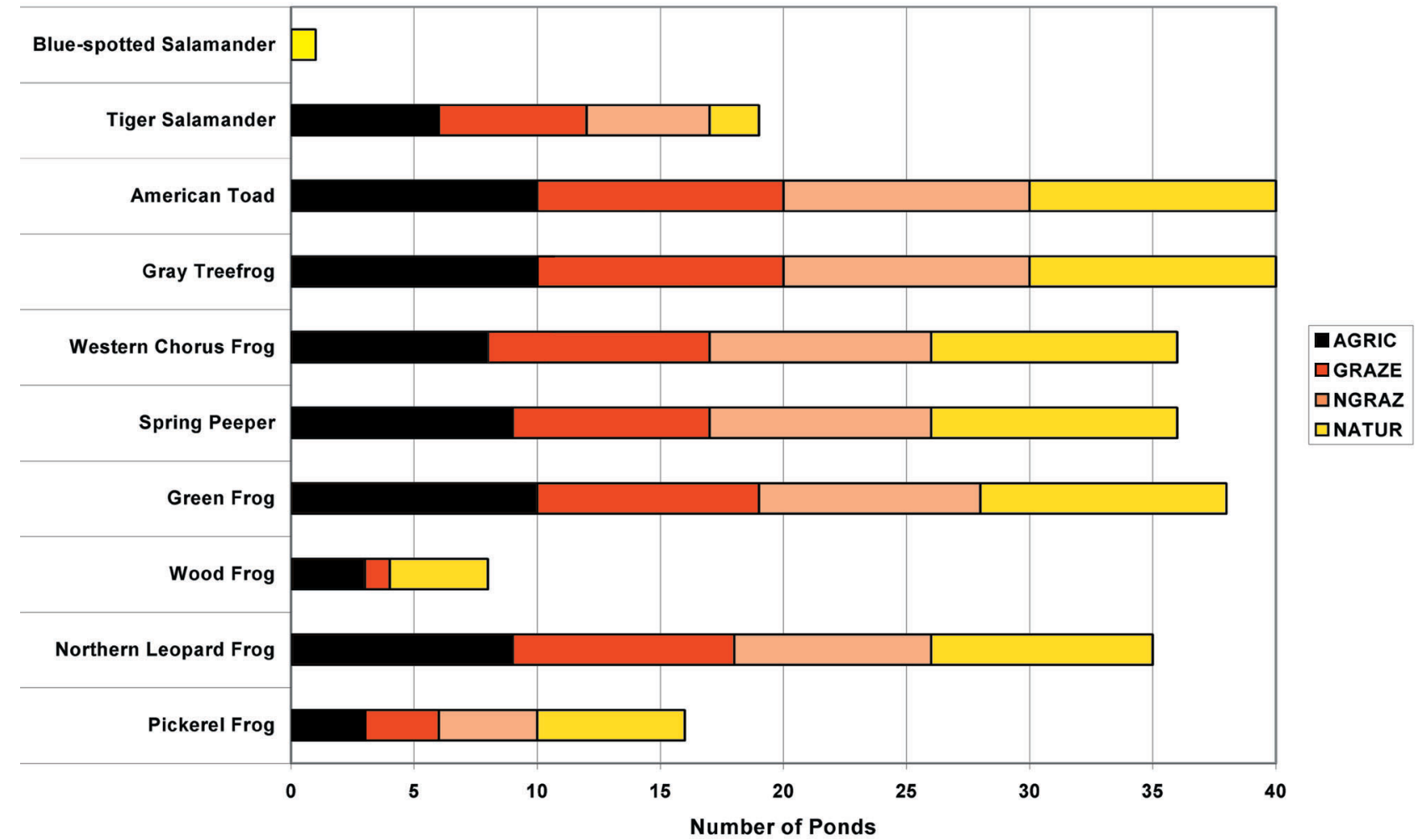

Amphibian species present within four types of surrounding land uses, based on detection by all survey methods, for farm ponds in Houston and Winona Counties, Minnesota, 2000-2001. Land use categories include agricultural (AGRIC), grazed (GRAZE), nongrazed (NGRAZ), and natural (NATUR).

examined in 2001. Of the 260 amphibians necropsied for parasites, only 11 were considered malformed, and 5 of these harbored Ribeiroia. Ribeiroia was found only in northern leopard frogs and green frogs.

A variety of other wildlife also used these ponds as habitat. We observed six species of snakes and two of turtles at ponds over the 2 years of the study. Common garter snakes (Thamnophis sirtalis) were the most frequently encountered reptile, followed by painted turtles (Chrysemys picta). We also observed 100 species of birds at the ponds. Song sparrows (Melospiza melodia) were observed most frequently, followed by red-winged blackbirds (Agelaius phoeniceus), common yellowthroats (Geothlypis trichas), and American robins (Turdus migratorius).

Based upon tracks observed at scent stations, 18 species of mammals visited the ponds. Raccoons (Procyon lotor) were detected at the most ponds, followed closely by the white-tailed deer (Odocoileus virginianus). We identified five species of fish in the ponds; the brook stickleback (Culaea inconstans) was most abundant. A wide variety of invertebrate taxa lived in the ponds. Midge larvae (Chironomidae), crawling water beetles (Haliplidae), and water boatmen (Corixidae) were the most common invertebrates.
We conclude that constructed agricultural ponds, originally designed for soil conservation purposes, are used by a variety of amphibians and other wildlife. With proper management, agricultural ponds provide suitable aquatic breeding habitat for amphibians. We recommend management actions such as limiting livestock access to the pond to improve water quality, reducing nitrogen input, and avoiding the introduction of fish into constructed ponds. The U.S. Department of Agriculture also recommends maintaining a wide grass buffer strip around the pond to trap sediment and nutrients.

See the project Web page for a poster and fact sheet on managing farm ponds.

http://www.umesc.usgs.gov/terrestrial/amphibians/ mknutson_5003869.html

\section{For more information, contact}

Melinda Knutson

USGS Upper Midwest Environmental Sciences Center 2630 Fanta Reed Road

La Crosse, WI 54603

Phone: 608.781 .6339

Email: mknutson@usgs.gov

\section{http://www.umesc.usgs.gov/}

